\title{
Hubungan Antara Harga Diri dengan Interaksi Sosial pada Orang dengan HIV AIDS di Yayasan Lantera Minangkabau Support
}

\author{
Yudhi Aulia $^{\text {a }}$, Ira Erwina ${ }^{a}$, Alfitri ${ }^{\text {b }}$ \\ ${ }^{a}$ Fakultas Keperawatan Universitas Andalas \\ ${ }^{b}$ Ruang Instalasi Rawat Inap (IRNA) Bedah dan Non Bedah \\ RSUP. Dr. M. Djamil Padang \\ Email : $\underline{\text { siaodhi@yahoo.com }}$
}

\begin{abstract}
PLWHA (People with HIV AIDS) is not just having problems physically or biologically, but also experience psychological problems, social and spiritual. When a person has been diagnosed with the HIV virus in the psychosocial assessment of PLWHA will withdraw from the environment. Disruption of self esteem affect communication PLWHA who are part of the process of social interaction. The purpose of this research is to know the extent of fatherly pride relationship with social interactions in people with HIV-AIDS. The research was conducted at Yayasan Lantera Minangkabau Support Padang from April to May 2013. This research is correlational cross-sectional approach. Total sample in this study of 45 PLWHA using total sampling technique. Collecting data using a questionnaire using a likert scale for the variable self-esteem and social interaction. Univariate data analysis done for the bivariate frequency distribution and performed with Spearman's test. The results showed as much as $91.4 \%$ of PLWHA have positive self esteem and $64.4 \%$ of PLWHA with good social interaction. There was no significant association between self-esteem and social interaction. The result is expected to be information and increase knowledge in promoting nursing care for PLWHA.
\end{abstract}

Keywords: people living with HIV, self-esteem, social interaction

\begin{abstract}
Abstrak: Orang dengan HIV AIDS bukan hanya mengalami masalah secara fisik atau biologis, tetapi juga mengalami masalah secara psikis, sosial dan spiritual. Ketika seseorang telah didiagnosa terkena virus HIV ini dalam pengkajian psikososialnya ODHA akan menarik diri dari lingkungannya. Terganggunya harga diri ODHA berpengaruh terhadap komunikasinya yang merupakan bagian proses dari interaksi sosial. Tujuan dari penelitian ini adalah unutk mengetahui sejauh mana hubungan harga diri dengan interaksi social pada orang dengan HIV AIDS. Penelitian ini dilakukan di Yayasan Lantera Minangkabau Support Padang dari bulan April hingga bulan Mei 2013. Jenis penelitian inni adalah korelasional dengan pendekatan cross sectional. Jumlah sampel pada penelitian ini sebanyak 45 ODHA dengan menggunakan teknik Total Sampling. Pengumpulan data menggunakan kuesioner yang menggunakan skala likert untuk variabel harga diri dan interaksi sosial. Analisa data univariat dilakukan dengan distribusi frekuensi dan untuk bivariat dilakukan dengan uji Spearman. Hasil penelitian menunjukkan sebanyak 91,4\% ODHA memiliki harga diri yang positif dan 64,4\% ODHA dengan interaksi sosial yang baik. Tidak terdapat hubungan yang bermakna antara harga diri dan interaksi sosial. Hasil penelitian ini diharapkan dapat menjadi informasi dan menambah pengetahuan dalam melaksakan asuhan keperawatan terhadap ODHA.
\end{abstract}

Kata kunci: ODHA, harga diri, interaksi sosial

HIV atau Human Immunodeficiency Virus, adalah virus yang menyerang sistem kekebalan tubuh manusia dan kemudian menimbulkan AIDS. HIV menyerang salah satu jenis dari sel-sel darah putih yang bertugas menangkal infeksi. Sel darah putih tersebut termasuk limfosit yang disebut $\mathrm{T}$ Limfosit atau sel T-4 atau disebut juga sel CD-4. Virus HIV diklasifikasikan ke dalam golongan lentivirus atau retroviridae (Djoerban, 2009). Virus ini secara material genetik adalah virus RNA yang tergantung pada enzim reverse trasciptase untuk dapat menginfeksi sel mamalia, termasuk manusia, dan menimbulkan kelainan patologi secara lambat. Virus ini terdiri dari 2 grup, yaitu HIV-1 dan HIV-2. Masing-masing grup mempunyai lagi berbagai subtipe, dan masing-masing subtipe secara evolusi yang cepat mengalami mutasi. Di antara kedua grup tersebut, yang paling banyak menimbulkan kelainan dan lebih ganas di 
seluruh dunia adalah grup HIV-1 (Zein, 2006).

AIDS singkatan dari Acquired Immuno Deficiency Syndrome artinya didapat, bukan penyakit keturunan. Immuno berarti sistem kekebalan tubuh. Deficiency artinya kekurangan, sedangkan syndrome adalah kumpulan gejala. AIDS berarti kumpulan gejala atau penyakit yang disebabkan oleh menurunnya kekebalan tubuh akibat infeksi oleh virus HIV. Berkurangnya kekebalan tubuh itu sendiri disebabkan berkurangnya sel CD4 karena diserang oleh virus HIV. Pada dasarnya, HIV adalah jenis parasit obligat yaitu virus yang hanya dapat hidup dalam sel atau media hidup. Seorang pengidap HIV lambat laun akan jatuh dalam kondisi AIDS (infeksi oportunistik), apalagi tanpa ada pengobatan. AIDS merupakan tahap akhir dari infeksi HIV (Djoerban \& Djauzi, 2009).

Infeksi HIV tidak akan langsung memperlihatkan tanda atau gejala tertentu. Sebagian memperlihatkan gejala tidak khas pada infeksi HIV akut, 3-6 minggu setelah infeksi. Gejala yang terjadi adalah demam, nyeri menelan, pembengkakan kelenjar getah bening, ruam, diare, atau batuk. Setelah infeksi akut, dimulailah infeksi HIV asimptomatik (tanpa gejala). Masa tanpa gejala ini umumnya berlangsung selama 8-10 tahun. Tetapi ada sekelompok kecil orang yang perjalanan penyakitnya amat cepat, dapat hanya sekitar 2 tahun (Djauzi, 2009).

HIV AIDS sampai saat ini memang belum dapat disembuhkan secara total. Namun, data selama 8 tahun terakhir membuktikan bahwa pengobatan dengan kombinasi beberapa obat anti HIV (obat anti retroviral) menunjukkan manfaat dalam menurunkan mordibitas dan mortalitas dini akibat infeksi HIV. Manfaat ARV dicapai melalui pulihnya sistem kekebalan ODHA dan pulihnya kerentanan ODHA terhadap infeksi oportunistik. Secara umum penatalaksanaan ODHA terdiri atas beberapa jenis, yaitu: 1. pengobatan untuk menekan replikasi virus HIV dengan ARV; 2. pengobatan mengatasi berbagai penyakit infeksi dan kanker yang menyertai infeksi HIV/AIDS, seperti jamur, tuberkulosis, hepatitis, toksoplasma, sarkoma kaposi, limfoma, kanker serviks; 3. pengobatan suportif, yaitu makanan yang mempunyai nilai gizi yang lebih baik dan pengobatan pendukung lain seperti dukungan psikososial. Dengan begitu harapan hidup lebih baik dan kejadian infeksi oportunistik berkurang (Nursalam, 2008 \& Djoerban, 2009).

UNAIDS atau United Nations Programme on HIV/AIDS telah mencatat jumlah penderita HIV/AIDS sampai dengan Desember 2012 diseluruh dunia jumlahnya 34 juta jiwa. Dimana 50\% diantaranya telah mengetahui status HIV mereka. Kemudian statistik kasus HIV/AIDS di Indonesia melaporkan bahwa tahun 2010 hingga 2011 terjadi peningkatan jumlah kasus sebanyak 21.031 HIV dan 6.178 AIDS, lalu pada tahun 2011 hingga 2012 terjadi lagi peningkatan yang signifikan yaitu dengan 15.372 kasus HIV dan 3.541 kasus AIDS terbaru. Sehingga jumlah kasus dari tahun 1987 sampai dengan Desember 2012 telah tercatat sebanyak 98.390 kasus HIV dan 42.887 kasus AIDS.

Untuk data perprovinsi, provinsi Sumatera Barat menduduki peringkat ke-13 dari 33 provinsi dengan jumlah kasus HIV sebanyak 658 dan kasus AIDS sebanyak 715. Kota Padang merupakan peringkat pertama dengan laporan peningkatan angka kejadian pada tahun 2010 hingga 2011 sebanyak 72 kasus HIV/AIDS, kemudian pada tahun 2011 hingga 2012 sebanyak 34 kasus baru HIV/AIDS. Jadi berdasarkan data KPA Kota Padang, jumlah kasus hingga 2012 tercatat 480 jiwa yang terinfeksi HIV/AIDS.

Seiring peningkatan kasus HIV/AIDS membuat semakin banyak persoalan HIV/AIDS yang memberikan dampak buruk. Angka prevalensi dan insiden telah menunjukkan bahwa banyak negara berkembang mengalami beban yang berlebih dibandingkan dengan kemampuannya untuk mengatasi penyakit ini . Meliputi hampir 
seluruh aspek biologis, psikososial dan spiritual (Spiritia, 2013).

Secara biologis virus HIV ini semakin lama akan berdampak pada memburuknya kekebalan tubuh, dimana ODHA mulai menampakkan gejala-gejala akibat infeksi oportunistik, yang merupakan tahap akhir terinfeksi HIV. Penyakit oportunistik biasanya dalam bentuk bentuk infeksi dan sebagian kecil berkembang dalam bentuk neoplasma yang tidak lazim seperti sarkoma kaposi, limfoma dan karsinoma serviks. Infeksi oportunistik termasuk juga jamur pada mulut, jenis kanker yang jarang, dan penyakit tertentu pada mata, kulit dan sistem saraf (Spiritia, 2012).

Selain itu apabila seseorang telah sampai pada tahap infeksi oportunistik ini, akan menimbulkan masalah harga diri dikarenakan perubahan bentuk fisik dan merasa dirinya jelek sehingga dapat mempengaruhi tingkat harga diri seorang ODHA. Menurut Plummer (2007) pemahaman mengenai harga diri berhubungan erat dengan pemahaman mengenai konsep diri. Konsep diri merupakan susunan gambaran menyangkut apa yang kita pikirkan mengenai diri kita, dimana didalamnya terdapat harga diri terhadap apa yang bisa kita capai, apa yang kita pikirkan mengenai pikiran orang lain mengenai kita, dan mau jadi apa kita.

Sedangkan menurut Rakhmat (2003) mendefinisikan konsep diri sebagai pandangan dan perasaan seseorang tentang dirinya. Persepsi ini bersifat psikologi, sosial, dan fisis. Persepsi yang bersifat psikologi, yaitu pemahaman seseorang tentang wataknya, misalnya hal-hal yang menyebabkan ia merasakan sedih, bahagia, cemas, dan sebagainya. Kemudian persepsi yang bersifat sosial, antara lain adalah pandangan seseorang tentang bagaimana pandangan orang lain terhadap dirinya atau seberapa berharga dirinya bagi orang lain. Pandangan seseorang terhadap dirinya juga ada yang bersifat fisis, yaitu mengenai penampilan dan kemampuan dirinya yang bisa terlihat oleh orang lain. Salah satu komponen dari konsep diri adalah harga diri.

Harga diri sebagai sikap positif atau negatif individu terhadap dirinya. Seseorang yang memiliki harga diri atau penghargaan terhadap diri yang positif merasakan bahwa dia adalah seseorang yang berharga, menghargai diri apa adanya, tidak mencela apa yang dilakukannya, dan tingkatan dia merasa positif terhadap dirinya (Burns, 1993). Perasaan harga diri yang rendah ditunjukkan dengan penolakan diri, penghinaan diri, dan evaluasi yang negatif.

Dampak psikososial masih menjadi masalah yang serius bagi ODHA, karena tidak mudah bagi seseorang untuk menerima keadaan dirinya menyandang status sebagai orang dengan HIV/AIDS. Menurut WHO (2012), ketika seseorang telah didiagnosa terkena virus HIV ini dalam pengkajian psikososialnya klien akan menarik diri dari lingkunganya. ODHA juga merupakan makhluk sosial, dimana Aristoteles mengatakan bahwa setiap manusia itu termasuk ODHA adalah zoon politicon, makhluk yang saling berinteraksi dan berkehidupan sosial. Kehidupan sosial melibatkan lingkungan sekitar baik dari keluarga maupun masyarakat. Serta manusia punya naluri gregariousness, yaitu naluri untuk selalu hidup berkelompok atau bersama dengan orang lain.

Interaksi sosial adalah kontak atau hubungan timbal balik atau interstimulasi dan respons antar individu, antar kelompok atau antar individu dan kelompok (Maryati \& Suryawati, 2003). Interaksi sosial adalah hubungan antar manusia yang menghasilkan hubungan tetap dan pada akhirnya memungkinkan pembentukan struktur sosial (Murdiyatmoko \& Handayani, 2004). Interaksi sosial adalah hubungan antar manusia yang menghasilkan suatu proses pengaruh memengaruhi yang menghasilkan hubungan tetap dan pada akhirnya memungkinkan pembentukan struktur sosial (Susanto, 2007). 
Mengacu pada penelitian yang dilakukan Spiritia tahun 2012 mengenai aspek-aspek mutu hidup ODHA, didapatkan hasil bahwa $35 \%$ percaya diri seorang ODHA mempengaruhi kenyamanannya untuk berkomunikasi dengan orang lain..Kemudian menurut penelitian Alfebrina (2012) mengenai reaksi dari orang lain terhadap konsep diri ODHA $83.3 \%$ memiliki pandangan negatif terhadap ODHA. Terlihat bahwa unsur tersebut merupakan salah satu titik permasalahan terjadinya penyimpangan interaksi sosial pada ODHA, yang membuat harga dirinya merasa rendah karena pandangan yang bermacam-macam yang keluar dari lingkungannya. Dimana percaya diri merupakan bagian dari harga diri dan komunikasi juga merupakan proses dari interaksi sosial, dan lingkungannya sendiri merupakan tempat berinteraksi dan bersosial.

Buruknya interaksi sosial yang dialami oleh ODHA berkaitan dengan tingkat harga diri pribadi tersebut. Bentuk interaksi ODHA yang buruk adalah tidak adanya partisipasi dalam kegiatan di masyarakat seperti tidak mengikuti kegiatan gotong royong, kegiatan ibadah. Selain itu ODHA juga terkadang enggan untuk bersosialisasi dengan lingkungan sekitarnya. Mengacu pada penelitian yang dilakukan oleh Bentham (2011) mengenai dampak orang dengan HIV/AIDS pada hubungan sosial di tiga provinsi Cina dengan jumlah sampel 866 orang, menunjukkan bahwa $95 \%$ berdampak pada hubungan sosial dan interaksi mereka. Sedangkan menurut peneliti lainnya di Cina tahun 2011 didapatkan bahwa hidup dengan HIV/AIDS mengakibatkan masalah serius dalam interaksi sosial yang sering menimbulkan penolakan, pemutusan hubungan, dan penghindaran dari lingkungan.

Sesuai dengan wawancara yang peneliti lakukan pada 5 ODHA, 1 orang menyatakan bahwa ketidakpeduliannya terhadap reaksi yang ditimbulkan dari lingkungan ketika orang sekitar mengetahui statusnya sebagai seorang ODHA. Kemudian
4 orang lainnya menyatakan bahwa dengan status yang disandangnya saat ini membatasi ruang geraknya melakukan aktivitas, sementara mereka memiliki beberapa target atau pencapaian hidup terkait kesuksesannya. Berdasarkan fenomena mengenai dampak biologis serta psikososial yang terjadi maka peneliti ingin melakukan penelitian mengenai hubungan tingkat harga diri dengan interaksi sosial pada orang dengan HIV AIDS di Yayasan Lantera Minangkabau Support Padang. Peneliti memilih tempat ini untuk dijadikan tempat penelitian dengan alasan yayasan ini adalah satu-satunya lembaga sosial di kota padang yang menaungi dan mengayomi ODHA, serta dirasa kooperatif untuk kelancaran penelitian. Kemudian istimewanya penelitian ini terletak pada variabel yang akan diteliti, karena pada penelitian sebelumnya belum ada yang melihat dan mengaitkan hubungan mengenai harga diri ODHA terhadap interaksi sosialnya.

Tujuan dari penelitian ini untuk mengetahui hubungan harga diri dengan interaksi sosial pada orang dengan HIV AIDS di Yayasan Lantera Minangkabau Support Padang Tahun 2013

\section{METODE}

Penelitian ini menggunakan korelasional dengan pendekatan cross sectional study, dimana data yang menyangkut variabel dependen dan variabel independen dikumpulkan dan diamati dalam waktu yang bersamaan. Jumlah sampel yang digunakan pada penelitian ini adalah 45 orang. Penelitian dilakukan di Yayasan Lantera Minangkabau Support Padang pada tahun 2013 dimulai pada bulan Januari sampai Juni 2013 dan proses pengumpulan data dilakukan dari tanggal 01 - 30 April 2013 dengan memberikan kuesioner kepada responden.

\section{HASIL DAN PEMBAHASAN}

Hasil penelitian ini disajikan dalam dua bagian umum yaitu univariat, dan bivariat. 
Tabel 1 Distribusi frekuensi harga diri ODHA di Yayasan Lantera Minangkabau Support Padang tahun 2013

\begin{tabular}{lcc}
\hline Harga Diri & Frekuensi & \% \\
\hline Positif & 41 & 91.1 \\
Negatif & 4 & 8.9 \\
\hline Total & 45 & 100 \\
\hline
\end{tabular}

Dari tabel diatas diketahui bahwa dari

45 responden diantaranya dengan harga diri 41 responden $(91.1 \%)$ dengan harga diri positif.
Tabel 2 Distribusi frekuensi interaksi sosial ODHA di Yayasan Lantera Minangkabau Support Padang tahun 2013

\begin{tabular}{|c|c|c|}
\hline Interaksi Sosial & Frekuensi & $\%$ \\
\hline Baik & 29 & 64.4 \\
\hline Buruk & 16 & 35.6 \\
\hline Total & 45 & 100 \\
\hline
\end{tabular}

Tabel 3 Hubungan Harga Diri dengan Interaksi Sosial pada Orang Dengan HIV AIDS di Yayasan Lantera Minangkabau Support Padang 2013

\begin{tabular}{|c|c|c|c|c|c|c|c|c|}
\hline \multirow{3}{*}{$\begin{array}{l}\text { Harga } \\
\text { Diri }\end{array}$} & \multicolumn{4}{|c|}{ Interaksi Sosial } & \multirow{2}{*}{\multicolumn{2}{|c|}{ Jumlah }} & \multirow[t]{3}{*}{$p$-value } & \multirow[t]{3}{*}{$\mathbf{r}$} \\
\hline & \multicolumn{2}{|c|}{ Baik } & \multicolumn{2}{|c|}{ Buruk } & & & & \\
\hline & $\mathbf{N}$ & $\%$ & $\mathbf{N}$ & $\%$ & $\mathbf{N}$ & $\%$ & & \\
\hline Positif & 28 & 68,3 & 13 & 31,7 & 41 & 100 & 0,08 & 0,257 \\
\hline Negatif & 1 & 25,0 & 3 & 75,0 & 4 & 100 & & \\
\hline
\end{tabular}

Hasil analisis hubungan antara harga diri dengan interaksi sosial ODHA diperoleh bahwa 41 ODHA memiliki harga diri positif dengan interaksi sosial yang baik sebanyak 28 orang $(68,3 \%)$ dan 13 orang $(31,7 \%)$ ODHA memiliki interaksi buruk. Sementara itu dari 4 ODHA yang memiliki harga diri negatif sebanyak 1 orang $(25,0 \%)$ memiliki interaksi sosial baik dan 1 orang $(75,0 \%)$ memiliki interaksi sosial buruk.

Hasil uji statistik Spearman diperoleh nilai $\mathrm{p}=0,08$ dengan $\mathrm{r}=0,257$. Nilai $\mathrm{p}=0,08$ menunjukkan bahwa tidak terdapat hubungan yang bermakna antara harga diri dengan interaksi sosial pada ODHA di Yayasan Lantera Minangkabau Support Padang Tahun 2013.

\section{Gambaran Harga Diri ODHA}

Hasil mengenai harga diri ODHA di Yayasan Lantera Minangkabau Support Padang, diketahui bahwa dari 45 ODHA terdapat 41 ODHA $(91,1 \%)$ memiliki harga diri positif dan 4 ODHA $(8,9 \%)$ memiliki harga diri negatif.

Berbeda dengan hasil penelitian yang dilakukan Eni \& Gilang (2011) yang hasilnya menunjukkan bahwa sebanyak $40 \%$ ODHA dengan harga diri tinggi dan $60 \%$ ODHA dengan harga diri rendah.

Harga diri merupakan semua yang dirasakan dan dipikirkan seseorang mengenai dirinya, mencakup seluruh kepercayaan dan sikap seseorang terhadap dirinya (Rakhmat, 2003). Banyak faktor yang membangun harga diri seseorang. Salah satu faktor yang mempengaruhi perkembangan harga diri seseorang, yaitu penghargaan, penerimaan, dan perhatian yang diterima individu dari orang-orang terdekatnya; sejarah kesuksesan dan status seseorang dalam masyarakat; nilai-nilai dan aspirasi yang dianut individu; serta cara-cara individu dalam merespon penilaian dari lingkungannya (Coopersmith, 1967). 
Kemudian adapun sumber-sumber dari harga diri tersebut adalah power, significance, virtue dan competence. Power merupakan hal terpenting bagi individu untuk dapat mengendalikan situasi kehidupan yang mereka alami sendiri dan kemampuan untuk menyikapi pengaruh yang orang lain berikan. Harga diri meningkat ketika individu merasa dicintai, dihormati, dan mendapat kasih sayang dari orang yang berarti bagi dirinya. Kemudian faktor virtue atau kebajikan ketika individu merasa baik secara kepribadian, moral dan etika, lalu pencapaian harga diri yang positif juga melalui penilaian terhadap kesukesan yang diraih oleh pribadi tersebut (Townsend, 2009).

Dari hasil penelitian mengenai harga diri Orang Dengan HIV AIDS di Yayasan Lantera Minangkabau bisa dilihat bahwa hampir semua responden 41 ODHA $(91,1 \%)$ memiliki harga diri positif. Harga diri itu sendiri memiliki tiga aspek persepsi yaitu penilaian terhadap diri sendiri, penilaian penampilan secara fisik dan penilaian orang lain terhadap kita.

Sesuai dengan pertanyaan nomor 1 pada kuesinoer yaitu "Saya merasa yakin tentang kemampuan saya" terlihat pada master tabel bahwa hanya 2 orang saja yang menjawab "Tidak Setuju". Ini menunjukkan bahwa ODHA yang dihimpun dalam yayasan ini telah bisa melewati masa pencapaian harga dirinya. ODHA telah memahami aspek dari harga diri tersebut. Menurut Coopersmith (1967) individu yang prestasi kompetensi yang bagus tidak mengartikan kemampuannya tersebut sebagai kesuksesan, karena dia lebih bias menghargai dirinya apabila dia mempunyai kemampuan untuk mengontrol diri sendiri dan orang lain.

Kemudian bila dilihat dari karakteristik, semua responden merupakan orang yang telah bekerja. Hal ini berarti mengharuskan mereka untuk bertemu dengan orang banyak yang diperlukan kepercayaan diri untuk dapat melewati proses berkomunikasi dan saling berinteraksi. Berkaitan dengan itu pula mereka telah menerima penghargaan, penerimaan status dan perhatian dari orang lain. Hal ini akan mempengaruhi seseorang dalam menjadikan dasar penilaian orang tersebut terhadap dirinya sendiri. Seseorang akan menumbuhkan sikap positif ketika telah mendapatkan penghargaan, penerimaan dari orang-orang sekitarnya.

\section{Gambaran Interaksi Sosial ODHA}

Hasil penelitian mengenai interaksi sosial ODHA di Yayasan Lantera Minangkabau Support Padang tahun 2013, diketahui bahwa dari 45 ODHA terdapat 29 orang $(64,4 \%)$ memiliki interaksi sosial yang baik dan 16 orang $(35,6 \%)$ memiliki interaksi sosial buruk. Hal ini berarti ODHA memiliki interaksi yang baik dengan masyarakat dan lingkungannya yang mencakup interaksi sosial asosiatif dan disosiatif.

Hasil penelitian ini berbeda dengan penelitian Pian (2011) di Jakarta yang menunjukkan bahwa ODHA yang memiliki interaksi sosial positif sebanyak $12,5 \%$ dan ODHA dengan interaksi sosial buruk negatif $87,5 \%$. Penelitian ini menunjukkan bahwa ODHA memiliki interaksi yang buruk dalam kehidupan sosialnya. Hasil yang berbeda disebabkan oleh penelitian ini dilakukan pada suatu komunitas yang bersifat non yayasan yang sama sekali belum mendapatkan pemahaman nilai-nilai moral dan psikososial.

Menurut Febriana (2006), Interaksi sosial dapat dikategorikan ke dalam 2 bentuk yaitu: Interaksi sosial asosiatif dan interaksi sosial disosiatif.

Interaksi sosial asosiatif yakni interaksi yang mengarah kepada bentukbentuk asosiasi (hubungan atau gabungan) seperti : a) Kerja sama, yaitu suatu usaha bersama antara orang perorangan atau kelompok untuk mencapai tujuan bersama, b) Akomodasi, yaitu suatu proses penyesuaian sosial dalam interaksi antara pribadi dan kelompok-kelompok untuk meredakan pertentangan.

Interaksi sosial yang bersifat disosiatif, yakni mengarah kepada bentuk- 
bentuk pertentangan atau konflik, seperti: a) Persaingan, yaitu perjuangan yang dilakukan perorangan atau kelompok sosial tertentu untuk memperoleh kemenangan atau hasil secara kompetitif, tanpa menimbulkan ancaman atau benturan fisik terhadap lawan, b) Kontravensi, yaitu bentuk proses sosial yang berada di antara persaingan dan konflik, c) Konflik, yaitu proses sosial antar perorangan atau kelompok masyarakat tertentu akibat adanya perbedaan paham dan kepentingan yang sangat mendasar, sehingga menimbulkan gap atau jurang pemisah yang menghambat interaksi sosial di antara yang bertikai.

Berdasarkan penelitian ini diketahui bahwa $64,4 \%$ ODHA yang memiliki interaksi sosial yang baik. Dilihat dari karakteristik ODHA sendiri terkait dengan pekerjaannya, seluruh ODHA di Yayasan Lantera Minangkabau adalah orang yang memiliki aktivitas atau kesibukan yang rutin. Kegiatan itu berlangsung di luar rumah, yang mengharuskan ODHA untuk melakukan kontak sosial dan komunikasi dengan orang lain. Secara tidak langsung ODHA telah melewati masa-masa proses kembali ke kehidupan sosialnya. Mereka bertemu, berinteraksi dan bekerja bersama orang lain. ODHA telah mampu masuk ke kehidupan sosialnya. Menyesuaikan diri sedari didiagnosa sebagai Orang Dengan HIV AIDS.

Sesuai juga dengan pertanyaan pada kuesioner nomor 14 yaitu "Apakah anda sering tidak menegur atau menyapa apabila berselisih paham dengan keluarga atau orang sekitar?", hanya 3 orang yang menyatakan "Selalu". Hal ini menunjukkan bahwa sebagian besar ODHA telah memahami bentuk-bentuk interaksi sosial itu seperti apa dan sudah mengetahui ciri-ciri dari interaksi sosial yang baik itu sendiri.

Kemudian dalam penelitian ini juga terlihat 16 orang $(35,6 \%)$ responden memiliki interaksi sosial yang buruk. Menurut Ahmadi (2002) interaksi sosial dipengaruhi oleh beberapa faktor, pertama yaitu faktor imitasi yang berarti proses interaksi sosial berasal dari proses alami yang melihat kemudian meniru. Faktor kedua adalah sugesti, sugesti yang dimaksud disini adalah pengaruh psikis baik yang datang dari orang lain maupun dari dirinya sendiri yang pada umumnya datang tanpa ada kritikan. Kemudian yang ketiga faktor identifikasi pribadi dan yang terakhir faktor simpati.

Bila dilihat dari master tabel untuk pertanyaan sehubungan dengan interaksi bersama keluarga . terlihat bahwa hubungan keluarga dengan ODHA dalam proses interaksi, sesuai dengan hasil penelitian IYW yang menyebutkan bahwa adanya hungan respon keluarga terhadap interaksi sosial ODHA.

Sehubungan dengan itu juga di Budaya Minangkabau mengatakan bahwa memiliki keluarga dengan penyakit yang ganas merupakan suatu AIB yang harus ditutup rapat-rapat oleh pihak keluarga. Bahkan tak jarang keluarga mengucilkan si penderitadan membuang jauh-jauh hubungan kekeluargaannya.

\section{Hubungan Harga Diri dengan Interaksi Sosial ODHA}

Hasil penelitian yang telah dilakukan mengenai harga diri dengan interaksi sosial ODHA di Yayasan Lantera Minangkabau Support didapatkan nilai $\mathrm{p}=0,08$ dengan nilai $r=0,257$. Hal ini berarti hipotesis peneliti yang berbunyi adanya hubungan antara harga diri dengan interaksi sosial tidak dapat diterima.

Hasil penelitian ini berbeda dengan penelitian Yayasan Spiritia (2012) yang menyatakan lebih dari 50,0\% tingkat percaya diri ODHA berpengaruh terhadap kehidupan sosial (sebaya) ODHA. Selaras dengan penelitian yang melihat hubungan antara harga diri dengan lingkungan sekitarnya (keluarga, pacar dan teman) menunjukkan bahwa terdapat hubungan yang berarti dari kedua variabel tersebut.

Harga diri terbentuk melalui interaksi individu dengan orang lain. Interaksi positif dapat membangun kepercayaan individu 
mengenai keadaan dirinya, sehingga individu memilki pandangan positif terhadap dirinya. Sebaliknya interaksi yang negatif dapat membuat individu memandang dirinya dengan cara yang negatif. Perhatian dan penghargaan yang diberikan orang lain, memberi efek positif dalam relasi manusia dengan lingkungannya (Sarason,1990). Cobb (1990) menyatakan bahwa peranan utama dukungan sosial adalah memberikan informasi kepada individu, bahwa orang lain memberikan perhatian dan menghargainya. Perhatian dan penghargaan dari orang lain dapat memberikan keyakinan kepada individu, bahwa dirinya merupakan orang yang cukup berharga untuk diperhatikan dan dibutuhkan. Perasaan tersebut dapat mendorong seseorang untuk menjalankan prilaku yang lebih sehat (Sarafina,1994).

Dalam penelitian ini dapat diketahui dari 41 ODHA memiliki harga diri positif dengan interaksi sosial yang baik sebanyak 28 orang $(68,3 \%)$ dan 13 orang $(31,7 \%)$ memiliki interaksi buruk. Menurut Spiritia (2010) terdapat hubungan yang berarti antara kepercayaan diri yang merupakan bagian dari harga diri dengan kenyamanan ODHA dalam berinteraksi dengan orang lain .

Bentuk-bentuk interaksi sosial itu sendiri adalah interaksi sosial bersifat asosiatif dan interaksi sosial bersifat disosiatif (Febriana, 2006). ODHA yang mampu berinteraksi sosial dengan baik akan , terbentuknya interaksi pada ODHA karena terlibatnya secara aktif ODHA tersebut dengan kegiatan-kegiatan yang ada di masyarakat maupun di lingkungan keluarga, hal ini sangat mempengaruhi kesehatan fisik, mental maupun spiritual ODHA tersebut.

Sementara itu dari penelitian ini juga diketahui 4 ODHA yang memiliki harga diri negatif sebanyak 1 orang $(25,0 \%)$ memiliki interaksi sosial b .giewbaik dan 3 orang $(75,0 \%)$ memiliki interaksi sosial buruk.

Tidak terdapatnya hubungan yang bermakna antara harga diri dan interaksi sosial ODHA, hal ini terjadi disebabkan oleh banyak faktor. Pertama faktor internal yang berasal dari diri ODHA sendiri, ODHA telah mampu mengartikan setiap stigma yang muncul dari lingkungannya. Sehingga dengan keadaan dirinya sekarang ODHA telah mampu menepis semua pandangan yang keluar dari lingkungan sekitar terhadap dirinya.

ODHA yang menjadi responden pada penelitian ini merupakan ODHA yang telah dihimpun dalam suatu yayasan sosial. Mereka telah berada pada lingkungan dengan keadaan yang sama dan senasib, yaitu di Yayasan Lantera Minangkabau. Faktor ini begitu besar pengaruhnya terhadap perkembangan harga diri dan interaksi sosial ODHA. Mereka telah dapat menanamkan nilai-nilai agama dan moral seperti yang telah dipahami melalui beberapa program yang diberikan yayasan, sehingga tidak terjadi penyimpangan yang krusial dalam dirinya.

\section{KESIMPULAN DAN SARAN}

Penelitian ini dapat disimpulkan bahwa sebanyak 41 ODHA (91.4\%) memiliki harga diri yang positif. Kemudian sebanyak 29 ODHA (64.4\%) memiliki interaksi yang baik. Tidak terdapat hubungan bermakna $(\mathrm{p}=0.08)$ antara harga diri dengan interaksi sosial pada orang dengan hiv aids di Yayasan Lantera Minangkabau Support Padang.

Disarankan perlunya intervensi terhadap interaksi sosial ODHA, dan melibatkan keluarga juga dalam penanganan masalah ini.

Bagi peneliti selanjutnya disarankan untuk dapat melakukan penelitian dengan responden yang berada dalam lingkungan non yayasan, yaitu yang belum mendapatkan pemahaman nilai-nilai moral dan psikososial.

\section{DAFTAR PUSTAKA}

Arikunto (2006). Prosedur Penelitian Suatu Pendekatan Praktik. Jakarta : Rineka Cipta.

Atkinson, R. L. Atkinson, R. C \& Hilgard, E. R. (1992). Pengantar psikologi. Jilid II. Jakarta: Erlangga

Azwar, S. (2007). Metode penelitian. Yogyakarta: Pustaka Pelajar. 
Azwar, Syaifuddin. (2010). Penyusunan Skala Psikologi. Yogyakarta : Pustaka Belajar

Boeree, C. George. (2008). General Psychology: Psikologi Kepribadian, Persepsi, Kognisi, Emosi, \& Perilaku. Yogyakarta :Prismasophie.

Burn, N \& Grove, S. K. (2001). The practice of nursing research: conduct, critique and utilization. $\left(4^{\text {th }}\right.$ ed). Philadelphia: W.B Saunders Company.

Calhoun \& Acocella. 1995. Psikologi tentang Penyesuaian dan Hubungan Kemanusiaan. Edisi 3. Semarang:

IKIP Semarang Press.

Coopersmith, S. (1967). The Antecedent of Self Esteem. San Fransisco: W.H. Freeman

Dahlan, S. (2011). Statistik Untuk Kedokteran dan Kesehatan (edisi 5). Jakarta: $\quad$ Salemba Medika.

Diaz, NV. (2010). AIDS-Realted Stigma with Interaction Social. Journal of University of Peurto Rico, 1-5

Djauzi, Samsuridjal. (2009). Ilmu Penyakit Dalam Edisi 2. Jakarta : EGC

Djoerban, Zubairi. (2009). Ilmu Penyakit Dalam Edisi 2. Jakarta : EGC

E. Usman Effendi dan Juhaya S. Praja.(1993). Pengantar Psikologi. Bandung: Penerbit Angkasa.

Franken, Robert E. (2002). Human Motivation. USA : Wadsworth

Gerungan, W.A. (2009). Psikologi sosial. Jakarta: Refika aditama.

Hariono. (2005). Penyimpangan Interaksi Sosial. Diambil Tanggal 20 Januari 2013 dari http://investopedia.com.

Indah. (2002). Bentuk-bentuk Interaksi sosial. Diambil pada Tanggal 20 Januari $2013 \quad$ dari http://wordpress.com.

Mariati dan Suryati. (2003). Pengertian Interaksi Sosial. Diambil pada Tanggal 21 Januari 2013 dari http//www.damandiri.or.id/file/mariat ipdf
Monks, F. J. (1998). Psikologi Perkembangan. Yogyakarta: Gajah Mada University Press

Moskowitz, DA. (2010). Self Esteem in HIV-Positive and HIV-Negative Gay and Bisexual Men. Journal of Self Esteem,1(2), 1-15

Nursalam. (2011). Konsep dan Penerapan Metodologi Penelitian Ilmu Keperawatan Edisi 3. Jakarta : Salemba Medika

Rahmad, Zaini. (2008). Proses Sosial dan Interaksi Sosial. Diambil pada Tanggal 19 Januari 2013 dari http://staff.fkip.uns.ac.id.

Sudjana. (1995). Metodologi Statistik. Edisi 3. Bandung : Tarsito.

Taylor, Shelley E. (1995). Health Psychology. Los Angeles : Library of Congress Cataloging-in-Publication

WHO. (2012). World Health Organization HIV/AIDS. WHO.

Zhang, Y. (2011). Effect HIV/AIDS on Social Relation in China. The AIDS Open Journal,5, 67-73 